\title{
Review Article \\ Institutional and Policy Assessment of Renewable Energy Sector in Afghanistan
}

\author{
Ahmad Murtaza Ershad \\ Energy Engineering Department, Faculty of Engineering, Kabul University, Kabul, Afghanistan \\ Correspondence should be addressed to Ahmad Murtaza Ershad; amershad@ku.edu.af
}

Received 16 June 2016; Accepted 18 October 2016; Published 15 January 2017

Academic Editor: Abhijeet P. Borole

Copyright ( 2017 Ahmad Murtaza Ershad. This is an open access article distributed under the Creative Commons Attribution License, which permits unrestricted use, distribution, and reproduction in any medium, provided the original work is properly cited.

Renewable energy resources could play a vital role in the sustainable economic, social, and environmental development of Afghanistan. Heavy reliance of rural households on firewood, rising costs of fossil fuels, outdoor and indoor air pollution, and climate change are some of the challenges that can be addressed by diversifying our power production fuel inputs and adopting renewable energy technologies. In order to deploy and scale up renewable energy technologies and improve access to sustainable energy, clear policies and targets and dedicated institutions are crucial. Fortunately, Afghan government with the support of international community is setting ambitious targets for the renewable energy sector and is encouraging national and international investors to take part in the generation, transmission, and distribution of renewable energy especially electricity through Power Purchase Agreements or very cheap land leases. Thus, the objectives of this report are (I) to review the existing institutions in the field of renewable energy, (II) to review renewable energy policies and targets in Afghanistan, and (III) to identify institutional and policy gaps and recommend solutions.

\section{Introduction}

Afghanistan is one of the least developed countries in the world located in south Asia bordering Islamic Republic of Iran from west, Pakistan from south and east, China from northeast, and Tajikistan, Uzbekistan, and Turkmenistan from north. It is located between latitude $29^{\circ} 35^{\prime}$ and $38^{\circ} 40^{\prime}$ degrees north and longitude $60^{\circ} 31^{\prime}$ and $75^{\circ} 00^{\prime}$ east. Its total land area is $652,864 \mathrm{~km}^{2}$ which is slightly smaller than the state of Texas. 2012-2013 estimated population is 25,500,100 excluding temporary Afghan refugees living in Iran and Pakistan and only about $24 \%$ of the population lives in urban areas $[1,2]$. Afghanistan has an arid and semiarid climate with rugged mountains and some plains in north and southwest [3].

Afghan society has been very vulnerable and insecure over the past few decades. It was ranked 175th on the United Nation's Human Development Index and the lowest in Asia in 2012 [4]. In 2008, 35\% of the population was unemployed and $36 \%$ of them lived under poverty line [5]. Literacy rate in 2010 was about $30 \%$ and is expected to increase to $50 \%$ by
2015 [6]. Gross national income (GNI) per Afghan was $\$ 680$ in 2012 [7]. Foreign aid plays a major role in the economy. Afghanistan received more than $\$ 56$ billion in development aid during 2002 and 2010 which translates to about $78 \%$ of GDP since 2003 [8]. In addition, foreign aid made up $69 \%$ of the national budget for the Fiscal Year 2014-2015 [9].

Gross electricity consumption in Afghanistan was $178 \mathrm{kWh}$ per capita in 2013 [10]. Annual gross demand for the whole country is expected to increase from $3,531 \mathrm{GWh}$ (2011) to $18,409 \mathrm{GWh}$ (2032) and annual peak demand from $742 \mathrm{MW}$ (2011) to 3,502 MW (2032) [8]. This growth in demand means that Afghanistan will need about five times more electrical energy than what was produced in 2011. Only $23.8 \%$ of the population was connected to electricity grid [11] and this number is projected to reach about $83 \%$ by 2032 [8].

Biomass is still the dominant fuel source in both urban and rural Afghanistan. 79.9\% of Afghan residences use solid fuels for cooking while this number is $97.4 \%$ for space heating $[1,2]$. Urban households use LPG as their primary fuel for cooking while firewood and charcoal are the most important sources of fuel for heating. For rural households, bushes, 
TABLE 1: Afghan population using solid fuels for cooking and heating $[1,2]$.

\begin{tabular}{lcc}
\hline Residence & Cooking & Heating \\
\hline Urban & 32.5 & 99.1 \\
Rural & 93.4 & 92.3 \\
Kuchi & 99.8 & 100 \\
National & 79.9 & 97.4 \\
\hline
\end{tabular}

firewood, and animal dung, in this order, are the most important fuels used for cooking and firewood, and bushes and animal dung, in this order, are the most important fuels for heating. Table 1 shows the percentage of urban, rural, and Kuchi residences that use solid fuels for heating and cooking.

Afghanistan so far does not have an interconnected centralized power system; however, interconnection of all grid segments is proposed by year 2032 [8]. In addition, there are many decentralized local grids and stand-alone systems such as solar PV and diesel generators providing electricity.

Total installed capacity (not operating capacity) of existing grid-connected electricity generation assets and transmission lines reached about 1,354 MW including imports from Tajikistan, Uzbekistan, Iran, and Turkmenistan [12]. Imports account for about $62 \%$ of total grid-connected capacity, while hydropower and thermal (diesel-fired) power plants make up the rest each having about the same share. Recently, another $42 \mathrm{MW}$ of hydro capacity was added when the Afghan-India Friendship Dam started generation and work on another $100 \mathrm{MW}$ has just started. Currently about $134 \mathrm{MW}$ of decentralized power generators is installed around the country mostly in rural areas, more than half of which is diesel generators.

Renewable energy resources such as hydro, wind, solar, and to some extent biomass and geothermal resources are abundant in Afghanistan. Hydro resources have considerable potential to be utilized for power generation. Not surprisingly, the first power generation scheme was the $2.5 \mathrm{MW}$ Jabal-e-Seraj hydropower plant. Afghan rivers offer estimated 23,000 MW of hydropower potential. Currently, installed capacity of large hydropower plants $(300 \mathrm{KW}-100 \mathrm{MW})$ and micro-hydropower schemes (less than $100 \mathrm{KW}$ ) is around 293 MW.

Solar and wind energy resources of Afghanistan are excellent for applications such as water pumping, water heating, and power generation through centralized schemes, minigrids, and stand-alone systems. Afghanistan is considered to be a "sunbelt country" similar to latitude equal parts of the United States [13]. Annual average Global Horizontal Irradiance (GHI) in Afghanistan is $1,935 \mathrm{kWh} / \mathrm{m}^{2}$ [14]. So far, solar energy is mainly used for lighting purposes through photovoltaic conversion in the rural areas. Total installed capacity of solar photovoltaics is around $13 \mathrm{MW}$ mainly in the form of stand-alone systems. The largest solar energy system in Afghanistan is a $1 \mathrm{MW}$ solar PV system providing power for villages in the central province of Bamyan through a minigrid.

In the meantime, maximum theoretical potential of wind power is estimated to be $158 \mathrm{GW}$ mainly from Herat province in the west and Balkh and Parwan provinces in the north [15] out of which only about $1000 \mathrm{MW}$ of installed capacity is economically feasible [16]. Although it is unclear how much in $\mathrm{kW}$ of wind power is installed in Afghanistan due to lack of any industry reporting mechanism, it is estimated that total installed capacity of wind power is about $300 \mathrm{~kW}$ with the largest wind power system of $100 \mathrm{~kW}$ in the mountainous province of Panjshir.

Finally, there exists potential to generate biogas from animal manure in rural areas and electricity from municipal solid waste in urban areas [17]. The number of biogas digesters installed in Afghanistan is around 500 units mainly installed by Ministry of Rural Rehabilitation and Development (MRRD) (about 300 units in the south), AREA (Agency for Rehabilitation and Energy Conservation in Afghanistan) (about 100 units), and BORDA $\left(5 \times 9 \mathrm{~m}^{3}\right)$ producing an annual average 1,896 to 2,654 MWh (energy production from 500 units of $4 \mathrm{~m}^{3}$ and $6 \mathrm{~m}^{3}$ is calculated using $1 \mathrm{~m}^{3}$ biogas = $1.1 \mathrm{~L}$ petrol $=10.44 \mathrm{kWh}$ using $1 \mathrm{~L}$ petrol $=34 \mathrm{MJ}$ ) of thermal energy for cooking, water heating, and lighting.

Fortunately major local, national, regional, and international efforts are underway to increase access to reliable electricity, reduce use of unclean solid fuels for space heating and cooking, reduce the environmental impacts of transportation fuels, increase the share of renewable energy resources, and increase coordination between various stakeholders. Adoption of Power Energy Services Law, National Energy Policy, and Afghanistan National Renewable Energy Policy, establishment of Renewable Energy Coordination Committee, setting a target of $95 \%$ renewables by 2032 , development of a 20 -year renewable energy roadmap, and the development of the $100 \mathrm{MW}$ renewable energy package are some of the major achievements in the last few years.

\section{Institutions}

Key government institutions responsible for the development of energy sector in Afghanistan are Ministry of Energy and Water (MEW) and MRRD. Each one of these institutions has distinct mandates. However, there are times when they have to coordinate with each other. Ministry of Finance (MOF) and Ministry of Economy (MOEc) are concerned with planning and budgeting projects. DABS is the only independent state-owned utility in the country. Figure 1 shows the institutional arrangement in the rural energy sector. The following sections introduce some of the key existing and future institutions involved in the energy sector especially renewable energy.

2.1. Ministry of Energy and Water (MEW). Some of the main roles of MEW in developing the renewable energy sector in Afghanistan are to prepare policies, strategies, action plans, and laws, create a platform for decision-making, implement renewable energy projects, and help other developing agencies with security, land acquisition, and licensing issues. MEW is considered to be the nodal institution responsible for the development of renewable energy sector according to ANREP. MEW is mandated to develop, plan, and implement renewable energy projects at the national, provincial, 


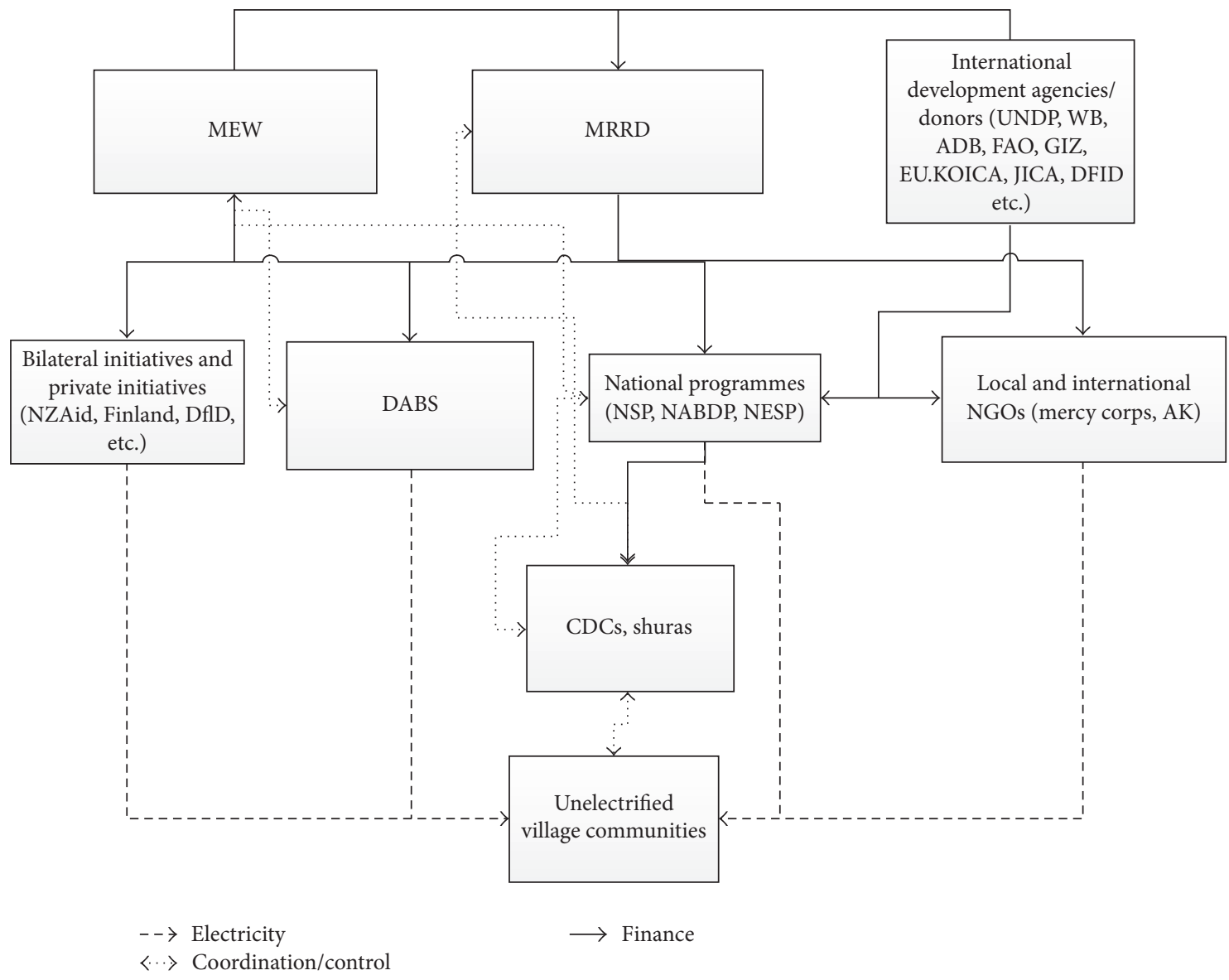

FIGURE 1: Institutional arrangement of rural energy sector (courtesy of UNDP 2014 (Afghanistan Sustainable Energy for Rural Development (ASERD) Project Document, UNDP, July 2014)).

and district levels. Implementation of projects greater than $1000 \mathrm{KW}$ is mandate of MEW and other private utilities such as DABS while that of projects smaller than $1000 \mathrm{KW}$ is mandate of MRRD. Renewable energy projects less than $100 \mathrm{~kW}$ are delicensed.

Renewable Energy Department (RED) which was built up in July of 2009 is the technical body concerned with the development of renewable energy projects at MEW. Biomass Department at RED is the responsible department for the development of other departments involved in the sector of renewables in MEW which are Energy Policy Directorate and Energy Programming Directorate. The following are some of REDs scope of work:

(1) Assessing REN potential and preparing detailed resource maps.

(2) Preparing provincial level REN master plans

(3) Developing technical designs, benchmarks, and performance standards

(4) Providing technical assistance and oversight to MRRD, DABS, and other GOs in designing and implementation of their REN projects

(5) Providing technical support to local industry and manufacturers on needs basis
(6) Providing technology specific and other technical inputs to MOF for designing fiscal incentives, specifically for facilitating the investment from the private sector

(7) Designing and implementing pilot and demonstration projects that support either new technology or innovative concepts such as the Public-PrivatePeople-partnership, women entrepreneur led REN projects, REN projects to support MDGs, and Post2015 Development Agenda, roof-top projects on government buildings

(8) Coordinating with donors and other funding organizations to ensure synergy of projects

(9) Facilitating technical training, awareness generation, and capacity building of stakeholders across GOs and NGOs

2.2. Ministry of Rural Rehabilitation and Development (MRRD). Promotion of rural energy services is mandate of MRRD to alleviate poverty and improve the livelihood of rural households. This mandate is at the village level. However, if there are projects that need to be implemented at the district level or provincial level or the scale of the project 
is bigger than what is specified $(1000 \mathrm{~kW})$ in the policies, then MRRD coordinates with MEW and/or DABS. MRRDs District Development Plans (DDPs) consider rural energy as one of the priority demands of communities.

Rural Energy and Enterprise Development (REED) Directorate is responsible for the rural energy issues at MRRD. In addition, rural energy projects at MRRD are implemented through National Solidarity Program (NSP) funded by UNDP and National Area Based Development Program's (NABDP's) Energy for Rural Development in Afghanistan (ERDA). ERDA is being scaled up to a new program called Afghanistan Sustainable Energy for Rural Development (ASERD) by joint initiative of MRRD and UNDP for implementation of subcomponent NPP-1 ARD Cluster. ASERD which was officially launched in the summer of 2015 plans to provide energy services with both electrical energy and thermal energy to about 110,000 households with a budget of 190 USD over five years. AERD's main components are energy supply, policy, capacity building, and piloting innovative technologies.

2.3. Da Afghanistan Breshna Sherkat (DABS). DABS is the only independent state-owned utility in the country owning all of the central generation, distribution, and transmission assets in Afghanistan. According to a MOU between MEW, DABS, and MOF, DABS is responsible for operation and management of power sector in Afghanistan. DABS was part of MEW prior to 2008 as DABM. DABS's focus is not really rural electrification since its main business is central gridconnected power generation units. Shares of DABS are owned by government. Ministries of Energy and Water, Finance, Economy, and Urban Development own shares of DABS. MEW owns 35\% of DABS's share. DABS bought 176 million USD worth of electricity from neighboring countries in 2013 and had forecasted another 205 million USD for 2014. This corresponds to $79 \%$ of energy supplied by DABS in 2014 . DABS's financial assets amount to about 561 million USD and its net income amounts to about 20 million USD.

2.4. The Energy Steering Committee (ESC). ESC is the highest decision-making body in the energy sector of Afghanistan meeting in the President's Office and is currently chaired by President's Senior Advisor on Technology and Infrastructure. Other members are Ministers of Energy and Water, Economy, Mines and Petroleum, and Finance and CEO of DABS.

2.5. Interministerial Commission for Energy (ICE). ICE was established by a presidential decree in 2006 for the purposes of donor and government stakeholder coordination and harmonizing investment plans in the energy sector. ICE is chaired by MOEc and its core members are MEW, DABS, MRRD, MOF, and MOMP. ICE has been very effective in investment and governance aspects of energy sector in Afghanistan coordinating five ministries, about 10 main development agencies, and other private sector partners and civil society organizations. ICE was closed in June 2012 due to lack of funding. ABD reports that, prior to its closure, ICE "has proved to be the most effective and coherent mechanism to brainstorm and agree on an investment and governance agenda." In May 2012, Afghan government approached ADB to support its efforts in coordinating the activities of its energy sector in (i) sector discussions, (ii) sector planning and harmonization, (iii) investment sequencing, and (iv) analytical work related to Afghanistan's energy sector. Fortunately, ICE was reestablished under an ADB project (Project \# 46347-001) that was approved on Feb 22, 2013, in order to institutionalize it and assure its sustainability as nearly 5 billion USD grant money is estimated to go into the energy sector of Afghanistan during 2013-2015. ADB project to fund ICE's activities is planned to close on March 31, 2015. Impact, outcome, and activities of ADB project \# 46347-001 to reestablish and support ICE are described in the below paragraph taken from ADB Technical Assistance Report published in Feb 2013.

"The impact will be effective coordination between energy sector stakeholders in Afghanistan to boost the grid-connected electrification ratio from less than $25 \%$ in 2012 to $50 \%$ by 2020. The outcome will be greater capacity of energy managers to support sector coordination, integrated policy and planning, governance, and implementation through (i) annual updating of the power sector master plan and a 20-year Afghanistan energy investment program beginning in 2014; (ii) approval of the Afghanistan Electricity Law (including clear definition of roles of stakeholders, private sector participation, and regulatory regime) by December 2014; (iii) approval by the joint monitoring and coordination board of the Afghanistan National Energy Supply Program (Energy NPP) by December 2014; and (iv) institutionalization of the power sector master plan and establishment of a secretariat in MEW by December 2014."

The main output of this project is to reestablish ICE so that it acts as a unifying body in the energy sector. Right now, ICE has a website that includes a database of energy projects and also has recently published its first quarterly (2014) report of the energy sector.

2.6. Renewable Energy Coordination Committee (RECC). RECC and its technical working groups (TWG) have been established for the purpose of the coordination of the efforts of MEW, MRRD, and DABS in the field of renewable energy in Afghanistan. Thus, it is joint initiative by MEW and MRRD. ICE Subcommittee on Renewable Energy and Rural Electrification with the financial support of GIZ-ESRA established RECC and TWG in 2012. Although ICE was closed in 2012, RECC continued to receive funding. RECC is chaired by both Deputy Ministers of MEW and MRRD. The following diagram (taken from Afghanistan Renewable Energy Sector Presentation by Aman Ghalib, Head of RED, Sep 2014) shows the roles of RECC and ICE in the renewable energy sector. Currently, RECC has one staff assigned by GIZ to manage the meeting.

As per RECC's new TOR (author has access to RECC's terms of reference drafted on Feb 2016 which is prepared by 
GIZ and is about to be adopted), RECC will be responsible to oversee the implementation of Afghanistan National Renewable Energy Policy (ANREP) at the Ministry of Energy and Water. The overall objectives of RECC are

(i) to ensure implementation and monitoring of the National Renewable Energy Policy and Strategy for renewable energy development,

(ii) to ensure coordination and cooperation between the two main ministries involved in REN and their relevant stakeholder organizations,

(iii) to identify policy and strategy needs for renewable energy and ensure these needs are attended to by relevant ministries and programs,

(iv) to attend to the needs of the Provincial Energy Commissions.

In order to achieve the above objectives, RECC has created the following technical working groups:

(1) Education, research, and innovation technical working group to be led by Kabul University Energy Engineering Department

(2) Private sector technical working group to be led by Afghanistan Chamber of Commerce and Industries (ACCI)

(3) Environment and energy efficiency technical working group to be led by National Environment Protection Agency (NEPA)

(4) Women affairs technical working group to be led by Ministry of Women Affairs.

The above technical working groups will report RECC and RECC will then report to ICE.

\section{Policies and Targets}

Primary objectives of renewable energy policies around the world are to maintain or expand energy services, improve energy access and security, and reduce health and environmental impacts of energy use. Other secondary objectives are improving opportunities for education, job creation, rural economic development, poverty reduction, and gender equality. By early 2014, at least 144 countries had renewable energy targets and 138 countries had renewable energy support policies in place [18]. Five out of six of our neighboring countries except Turkmenistan have already established some kind of regulatory policy or financing mechanism for renewable energy development (Table 2).

Most of the policy documents shown in Table 2 focus on the power sector and not the heat sector. However, some policy developments could be seen in the renewable heating and cooling sector as well. As for early 2014, at least 24 countries had adopted renewable heating (and cooling) targets, and at least 19 countries had obligations at the national or state/provincial level [18]. Government rebates are available in some countries for the adoption of household biomass energy systems such as biogas and fuel-efficient cook stoves.
TABLE 2: Policies and financing mechanisms adopted in Afghanistan neighboring countries and India as of the end of 2013.

\begin{tabular}{|c|c|}
\hline Country & $\begin{array}{l}\text { Regulatory policies/public financing/fiscal } \\
\text { incentives }\end{array}$ \\
\hline \multirow{5}{*}{ Pakistan } & (1) RE targets \\
\hline & (2) FIT policy \\
\hline & (3) Net metering policy \\
\hline & (4) Capital subsidy and rebates \\
\hline & (5) Public investment, loans, or grants \\
\hline \multirow{4}{*}{ Iran } & (1) Feed-in tariff (FIT) policy \\
\hline & (2) Investment or production tax credits \\
\hline & (3) Energy production payments \\
\hline & (4) Public investment, loans, or grants \\
\hline \multirow{2}{*}{ Tajikistan } & (1) RE targets \\
\hline & (2) FIT policy \\
\hline Turkmenistan & None \\
\hline Uzbekistan & (1) Tendering policy \\
\hline \multirow{11}{*}{ China } & (1) RE targets \\
\hline & (2) FIT Policy \\
\hline & (3) Renewable Portfolio Standard (RPS) \\
\hline & (4) Tendering policy \\
\hline & (5) Heat obligations \\
\hline & (6) Biofuels obligations \\
\hline & (7) Capital subsidy or rebate \\
\hline & (8) Investment or production tax credits \\
\hline & (9) Reduction in sales or energy taxes \\
\hline & (10) Energy production payments \\
\hline & (11) Public investment, loans, or grants \\
\hline \multirow{10}{*}{ India } & (1) RE targets \\
\hline & (2) FIT policy \\
\hline & (3) Renewable Portfolio Standard (RPS) \\
\hline & (4) Tendering policy \\
\hline & (5) Heat obligations \\
\hline & (6) Biofuels obligations \\
\hline & (7) Capital subsidy or rebate \\
\hline & (8) Investment or production tax credits \\
\hline & (9) Energy production payments \\
\hline & (10) Public investment, loans, or grants \\
\hline
\end{tabular}

Renewable heating and cooling is also supported through fiscal incentives, as well as through building codes and other measures at the national and local levels in several countries.

Over the last few years, Afghanistan has also started to realize the importance of drafting policies and strategies for the renewable energy sector with the help of the international community. However, the focus has been mostly on electricity generation with a limited focus on affordable and efficient cooking and heating devices run on either renewable energy sources or traditional biomass. Table 3 shows the list of the documents that relate to renewable energy development 
TABLE 3: Renewable energy development related documents in Afghanistan.

\begin{tabular}{llccc}
\hline No. & Document & Year drafted & Responsible institution(s) & Status as of Jan 2015 \\
\hline 1 & Energy Sector Strategy & 2008 & MEW and MRRD & Adopted \\
2 & National Energy Supply Program & 2013 & MEW & Adopted \\
3 & National Water and Natural Resources Development Program & NA & MEW, MRRD, MAIL, MCN & Adopted \\
4 & Rural Renewable Energy Policy & $2013 / 2014$ & MEW, MRRD & Drafted/not adopted \\
5 & Afghanistan National Renewable Energy Policy & 2015 & MEW & Adopted \\
7 & Afghanistan Power Sector Master Plan & 2013 & MEW & Adopted \\
8 & Energy Services Law & 2015 & MEW & Adopted \\
9 & Afghanistan National Renewable Energy Strategy & 2015 & MEW & Drafted \\
10 & Afghan National Renewable Energy Action Plan & 2015 & MEW & Drafted \\
11 & Renewable Energy Roadmap & 2016 & MEW & Ongoing \\
\hline
\end{tabular}

drafted by the government and international community. The following sections summarize some of the below documents.

\subsection{Energy Sector Strategy (EES-2008). Energy Sector Strat-} egy (ESS) was developed by the ANDS Secretariat and submitted for approval by sector responsible authorities (Ministers of Energy and Water, Rural Rehabilitation and Development, and Mines and Petroleum) in February 2008. EES was developed for the energy sector under Pillar III, Infrastructure, and Natural Resources, to achieve the third goal of ANDS, social and economic development. EES focuses more on electricity generation rather than clean energy for cooking and heating. The following five pillars make the basis of the short-term strategies of the energy sector:

\section{(1) Increased Efficiency in Existing Operation}

(2) Improved Sector Governance and Public-Private Partnership Promotion

(3) Improved Coordination and Capacity Development

(4) Rural Energy versus Rural Electrification

(5) Expanded or New Supply

However, in the long-term, EES recommends the government to focus more on cogeneration, distributed power, renewable energy, end-use energy efficiency, and more traditional energy supply schemes. EES emphasizes significantly on reduction of subsidies on projects and implementation of energy projects that generate income for the households and not just meet their basic needs of lighting. However, the neediest will still gain access to energy through subsidized rates. Table 4 summarizes some of the main outcomes and activities of EES regarding institutional and policy building in the energy sector.

3.2. National Energy Supply Program (NESP-2013). NESP is one of the 22 National Priority Programs (NPPs) that was agreed upon at the Kabul International Conference in 2010. NESP is one of the four NPPs under the Infrastructure Development Cluster. NESP tries to show the impacts of investment in the energy sector especially in the electricity subsector on the economic development of Afghanistan.
MEW is the primary executing ministry of NESP. However, MEW is expected to coordinate and cooperate with other related ministries and institutions such as DABS, MRRD, MAIL, and NEPA. The main goal of NESP is to prepare and implement activities toward increased energy access and sufficient, reliable, and affordable energy especially electrical energy.

NESP has identified five major areas of investment in the energy sector and MEW is responsible for reporting progresses made to the review program coordination board and Joint Coordination and Monitoring Board (JCMB). NESP is planned to be implemented during the period of Jan 2013-Dec 2014. The cost for the plan is estimated to be around USD 3.5 billion. Table 5 shows the five components of NESP with corresponding budget requirements.

With regard to improving institutional, policy, and regulatory frameworks, NESP outlines specific activities under components four and five. Some of the key outputs of components four and five are outlined below:

(i) the restructuring of energy institutions

(ii) building regulatory and policy frameworks to support private sector participation

(iii) building personal and institutional capacities of energy sector employees (DABS, MEW, and MRRD staff) and the staff of the private sector entities

(iv) establishing a strong coordination, oversight, communication, and management mechanism in the energy sector

(v) building the educational capacities of universities and vocational training centers

3.3. National Water and Natural Resources Development Program (NWNRD). NWNRD is one of the four NPPs under Agriculture and Rural Development Cluster (ARD). MEW, MRRD, MAIL, and MCI are the principle ministries of ARD Cluster. The goal of NWNRD program is to ensure the effective utilization of water and other natural resources and their proper management to foster agricultural productivity, safe drinking water, and viable rural energy options. One of the main objectives of NWNRD program is to improve energy access in rural areas in order to improve livelihoods 


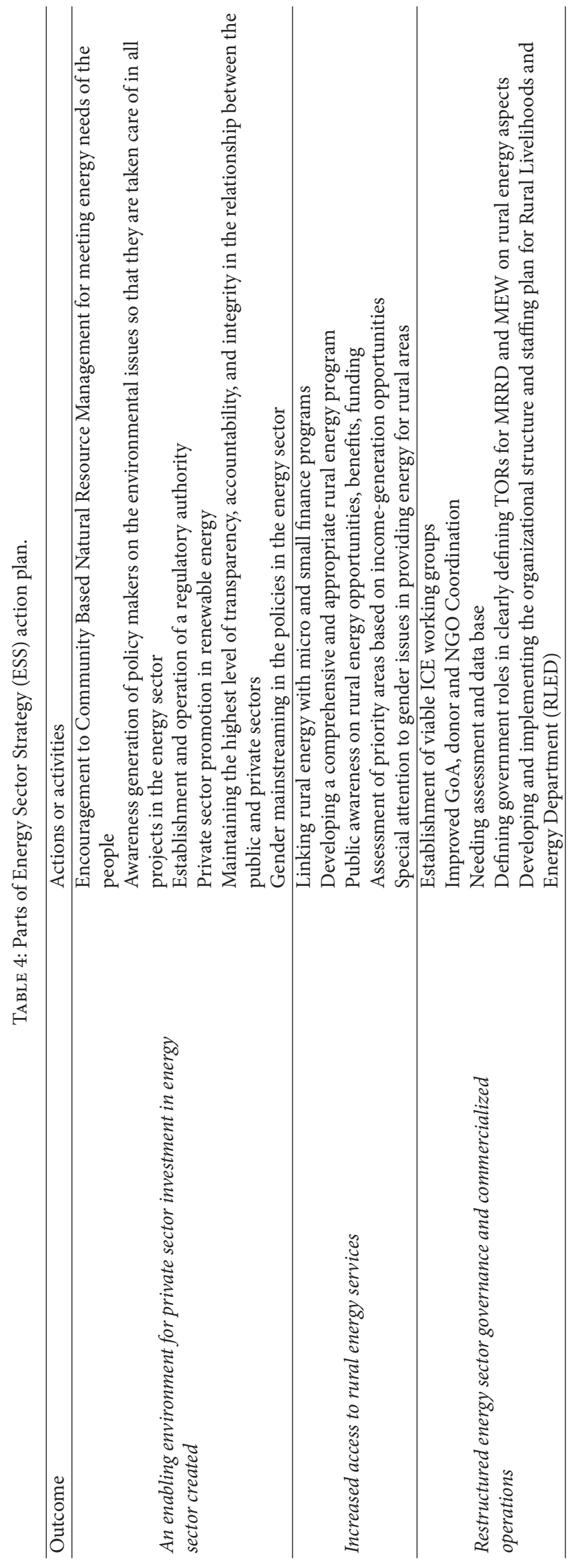


TABLE 5: NESP components and estimated budget.

\begin{tabular}{llc}
\hline No. & Component & $\begin{array}{c}\text { Budget (USD) } \\
\text { million }\end{array}$ \\
\hline 1 & Energy supply & 1,921 \\
2 & Energy transmission and distribution & 1,015 \\
3 & Energy efficiency and renewable energy & 59 \\
4 & $\begin{array}{l}\text { Energy institutions and private sector } \\
\text { participation }\end{array}$ & 334 \\
5 & $\begin{array}{l}\text { Capacity and regulatory framework } \\
\text { development }\end{array}$ & 135 \\
\hline & Total budget & 3,465 \\
\hline
\end{tabular}

TABLE 6: Components and subcomponents of NWNRD.

\begin{tabular}{lc}
\hline Components (C) and subcomponents (SC) & $\begin{array}{c}\text { Budget } \\
\text { (USD } \\
\text { million) }\end{array}$ \\
\hline C 1: Water resources and irrigation development & \\
SC 1: Institutional reform and capacity development & \\
SC 2: Land and water monitoring & \\
SC 3: Irrigation development & $1,558.41$ \\
SC 4: Water resources development and management & \\
SC 5: Flood protection and management & \\
SC: Rural water supply, sanitation, and hygiene & \\
promotion & \\
\hline C 2: Environmental management and rural energy & \\
SC 1: Biodiversity and land management & \\
SC 2: Energy for rural development in Afghanistan &
\end{tabular}

and create new sustainable jobs. Table 6 introduces the two components and subcomponents of NWNRD with their estimated budget. The budget for the components would come from donor funds channeled through either ARFT (Afghanistan Reconstruction Trust Fund) or a special account.

The main component dealing with energy is $\mathrm{C1}: \mathrm{SC} 2$ : Energy for Rural Development. The goal of the energy subcomponent is to increase access to modern sources of energy in rural areas. Objectives include designing rural energy projects together with sustainable institutional framework, ensuring the sustainability of these projects through capacity building, creation of community funds, and establishment of service centers for $\mathrm{O} \& \mathrm{M}$. The main outcome of $\mathrm{Cl}: \mathrm{SC} 2$ is to develop alternative energy sources in order to reduce the pressure of solid biomass in rural areas of Afghanistan. It is estimated that, in ten years, $10 \%$ improvement will be met.

3.4. Rural Renewable Energy Policy (RREP-2013). RREP is drafted by MEW and MRRD with the strategic objective of creating better social, economic, and environmental conditions for the rural population of Afghanistan. Specific objectives of RREP are to increase income generation of households by increasing energy access, provide affordable, clean, and sustainable lighting, heating, and cooking devices, reduce health and environmental impacts of energy use, and improve opportunities for income generation, poverty alleviation, and energy efficiency.

To attract private sector involvement and promote the sustainability of rural renewable energy projects, the government has to introduce certain regulatory measures such as the introduction of legal frameworks for pricing and tariff structures, establishment of procedures to integrate local renewable energy schemes to the national grid, creation of power purchase agreements, and grid codes. Safety and quality standards need to be developed by ANSA in coordination with MRRD and MEW regarding power generation, transmission, and distribution.

RREP is the first policy document that introduces an approach to the adoption of clean and sustainable biomass energy systems. Biogas is the only application of biomass resource; the following are approaches for the application of biomass energy for rural areas:

(i) Biogas will be promoted to replace the use of fuel wood and animal wastes as sources of energy for cooking.

(ii) Emphasis will be given to research to increase efficiency and to reduce the cost of household biogas production technology, including development and dissemination of community and institutional biogas plants.

(iii) The establishment of biogas-related information centers will be encouraged in coordination with local institutions.

(iv) Technology for the production of biomass gasification will be developed and disseminated through technology transfer.

(v) Consumption of biomass will be reduced and efficiency of fuelwood stoves is enhanced by expanding the use and local production of fuel-efficient stoves.

Poor institutional framework and infrastructure at the subnational level for rural energy promotion, lack of consumer awareness on the benefits and opportunities of renewable energy, financial, legal, regulatory, and institutional barriers, low capacity for the promotion of renewable energy technologies at all levels of government, private sector and nongovernmental organizations, and a strong focus of meeting the basic energy needs rather than focusing on production uses of energy for income generation are identified to be some of the barriers to the development of renewable energy in Afghanistan.

3.5. Afghanistan National Renewable Energy Policy (ANREP2015) (Afghanistan National Renewable Energy Policy, Final Draft: January 2015). ANREP was drafted with the initiation of MEW's Energy Policy and Renewable Energy Directorates and the technical and financial support of GIZ with the overall objective of deploying and utilizing renewable energy sources in an optimized manner. 
ANREP's targets have focused mostly on electricity generation with a limited focus on affordable and efficient cooking and heating devices run on either renewable energy sources or traditional biomass. However, its scope includes all sorts of stand-alone systems and devices for thermal energy. Fortunately, biomass energy projects are on the list of priority projects that need to be implemented. ANREP sets a power target of $4500 \mathrm{MW}-5000 \mathrm{MW}$ by 2032 but not any thermal energy targets. ANREP is supposed to be implemented in two terms: Term I (2015-2020) and Term II (2021-2032). The objective is to support PPP for the development of renewables in the first term and in the second term is dedicated to the full commercialization of renewable energy development.

With regard to institutional arrangements for the implementation of ANREP, it is expected that an Interministerial Commission on Renewable Energy (ICRE) would be established to oversee the implementation of ANREP in the first term and this entity would develop into an independent decision-making authority on renewable energy sources in the second term. ICRE is versioned to have statutory authority and be established by a presidential decree. In addition to ICRE at the national level, Zonal Renewable Energy Centers (ZRECs) will also be created to oversee the implementation of ANREP in various zones of Afghanistan.

\subsection{Afghanistan National Renewable and Rural Energy} Strategy (RRES-2014). RRES outlines Afghanistan's rural renewable energy action plans until 2020 and development objectives until 2032. RRES focuses on the development of renewable energy sources for economic development of rural areas through increasing energy access. The main emphasis is on sustainable electricity schemes. However, nonelectrical energy needs are also covered. RRES was planned to be acknowledged by MEW and MRRD and published by December 31, 2014. However, as for now, it is not yet published. MEW-RED is the responsible body for the implementation and advancement of RRES and is also responsible for overseeing the milestones specified in RRES. MEW-RED is expected to lead the implementation of RRES in close collaboration with MRRD-REED and the rest of the stakeholders in the sector. RRES is meant to be a "handon approach" to address energy needs in rural areas and describes how measures determined by ANREP and RREP are implemented.

Specific targets and actions regarding rural households' access to clean fuels or improved thermal energy devices are limited in RRES. The only target is that at least 2 million people in rural Afghanistan have access to sustainable and alternative fuels for cooking and space heating and/or gain access to improved means of cooking and space heating using traditional biomass fuels. With regard to institutional development, the following actions need to be taken:

(i) It is intended that by 2020, Renewable Energy Development Authority (REDA) is established that would act as an independent implementing agency of renewable energy projects.

(ii) MEW-MRRD Technical Working Group (TWG) needs to be continued. (iii) MEW-MRRD needs to continue ICE Subcommittee on Rural Electrification and Renewable Energy (ICE$\mathrm{RE})$.

(iv) Rural Energy Information Desk needs to be created in order to collect and disseminate renewable energy related information.

\section{Recommendations}

Lack of close coordination among institutions involved in RE development and commercialization, existence of dedicated government organizations and financing agencies, research institutes and organizations, microfinance institutions for consumer credit, and clear policies and targets are identified to be some of the main barriers to the development of renewables in Afghanistan. The following are a few recommendations specific to institutional and policy development that could help speed up the development of renewable energy technologies especially sustainable biomass energy systems in Afghanistan.

(1) RREP and ANREP should be reviewed to include specific targets for affordable and efficient cooking and heating devices run on either renewable energy sources or traditional biomass especially with a Community Based Natural Resources Management (CBNRM) approach. Right now the main focus of these policy documents is electrification. Fortunately, FAO-GEF climate change mitigation project has activities to review existing policies.

(2) Technology specific policies with careful strategies should be developed and innovative programs should be designed. These policies should focus more on renewable energy market development and private sector leadership rather than government led projects with very high rates of subsidies. For example, biomass policies could follow strategies such as introducing improved cook stove designs that make use of traditional biomass fuels rather than clean alternative fuels such as wood pellets and ethanol or other nonrenewable sources such as LPG, coal, and kerosene since these alternative fuels are not economically accessible. RREP is the first policy document that outlines a few approaches for the promotion of biogas in Afghanistan.

(3) In order to speed up the implementation of renewable energy projects, Interministrial Commission on Renewable Energy (ICRE) which is mentioned in ANREP for oversight and regulation of renewable energy developments should be established as soon as possible.

(4) A dedicated financing institution should be established in order for the government to be able to incentivize rural clean cooking and heating technologies and electrification schemes to address the barriers of higher initial investment costs through loans, grants, and tax reductions. These incentives can be financed through public and private financial 
resources. According to ANREP, dedicated institution shall be established during the period of 2021-2032. However, the government has to put more effort to make it happen much earlier than the targeted period.

(5) In order to support the growth of market for renewable energy technologies, public-private Market Facilitating Organizations (MFO) should be established or existing ones strengthened at the national, provincial, district, and village levels even [19]. These MFOs should improve networking, financing, and policy advocacy, user education, technical assistance, information dissemination, and other activities that would help the market for renewables. These MFOs should also increase awareness among potential investors and business communities regarding business opportunities available in rural energy markets. BORDA, a German NOG, for example, is the leading MFO for biogas in Afghanistan. FAO-GEF climate change mitigation project is making use of BORDA as technical service provider to help with the project implementation. The replication of this model to strengthen existing MFOs is highly recommended.

(6) Government, NGOs, and private sector are encouraged to incorporate innovative business models while implementing renewable energy projects [20]. Publicprivate partnerships (PPPs), pay-as-you-go (PAYG) micro payments, one-stop shops (organizations that both sell renewable energy products for a small downpayment and give loans for a period of time charged with interest rate), leasing (direct leasing and leaseto-own systems), franchise, or service models are some of the existing models. Afghanistan Sustainable Energy for Rural Development (ASERD) program is already planning to implement a minigrid project under PPP mode.

\section{Competing Interests}

The author declares that there are no competing interests.

\section{References}

[1] CSO, National Risk and Vulnerability Assessment (NRVL) 20112012, CSO, Kabul, Afghanistan, 2014.

[2] CSO, Population Statistics, Central Statistics Organization, Kabul, Afghanistan, 2014, http://cso.gov.af.

[3] NOAA, Climate of Afghanistan, National Climate Data Center, 2008, http://www.ncdc.noaa.gov/oa/climate/afghan/afghannarrative.html.

[4] UNDP, 2013 Human Development Report, United Nations Development Program Human Development Reports, 2013, http://hdr.undp.org/sites/default/files/reports/14/hdr2013_en_ complete.pdf.

[5] CIA, The World Fact Book: Afghanistan Economy. Retrieved from Central Intelligence Agency (CIA), March 2014, https:// www.cia.gov/library/publications/the-world-factbook/geos/af .html.
[6] ACCU, ACCU Asia-Pacific Cultural Center for UNESCO, 2010, http://www.accu.or.jp/esd/forum_esd_2010/program/program12_ 01/pdf/presentation5.pdf.

[7] “WB. (n.d.). Afghanistan,” The World Bank, April 2014, http:// data.worldbank.org/country/afghanistan.

[8] Fichtner, Islamic Repulic of Afghanistan: Power Sector Master Plan, Fichtner, Stuttgart, Germany, 2013.

[9] MoF, Reports \& Publications: National Budget, Ministry of Finance Directorate General Budget, Kabul, Afghanistan, 2015, http://www.budgetmof.gov.af.

[10] CSO, Economy Statistics: Mining and Energy. Retrieved from Central Statistics Organization (CSO), April 2015, http://cso.gov.af/.

[11] B. Spagnoletti and T. O'Callaghan, "Let there be light: a multiactor approach to alleviating energy poverty in Asia," Energy Policy, vol. 63, pp. 738-746, 2013.

[12] ICE, Energy Sector Status Summary Report, The Inter-Ministerial Commission for Energy Secretariat, Kabul, Afghanistan, 2016.

[13] R. K. Burns, "Afghanistan: solar assets, electricity production, and rural energy factors," Renewable and Sustainable Energy Reviews, vol. 15, no. 4, pp. 2144-2148, 2011.

[14] A. M. Ershad, R. J. Brecha, and K. Hallinan, "Analysis of solar photovoltaic and wind power potential in Afghanistan," Renewable Energy, vol. 85, pp. 445-453, 2016.

[15] NREL, International Activities: Afghanistan Resource Maps and Toolkits. Retrieved from National Renewable Energy Laboratory (NREL), May 2007, http://www.nrel.gov/international/ ra_afghanistan.html.

[16] Tetra Tech, Development of Wind Energy Meteorology and Engineering for Siting and Design of Wind Energy Projects in Afghanistan, Tetra Tech, Langhorne, Pa, USA, 2009.

[17] NREL, Biomass Resource Assessment in Afghanistan, NREL, Golden, Colo, USA, 2011.

[18] REN21, Renewables 2014: Global Status Report, REN21, Bonn, Germany, 2014.

[19] E. Martinot, A. Chaurey, D. Lew, J. R. Moreira, and N. Wamukonya, "Renewable energy markets in developing countries," Annual Review of Energy and the Environment, vol. 27, pp. 309-348, 2002.

[20] M. Hallett, "Distributed power in afghanistan: the padisaw micro-hydro project," Renewable Energy, vol. 34, no. 12, pp. 2847-2851, 2009. 

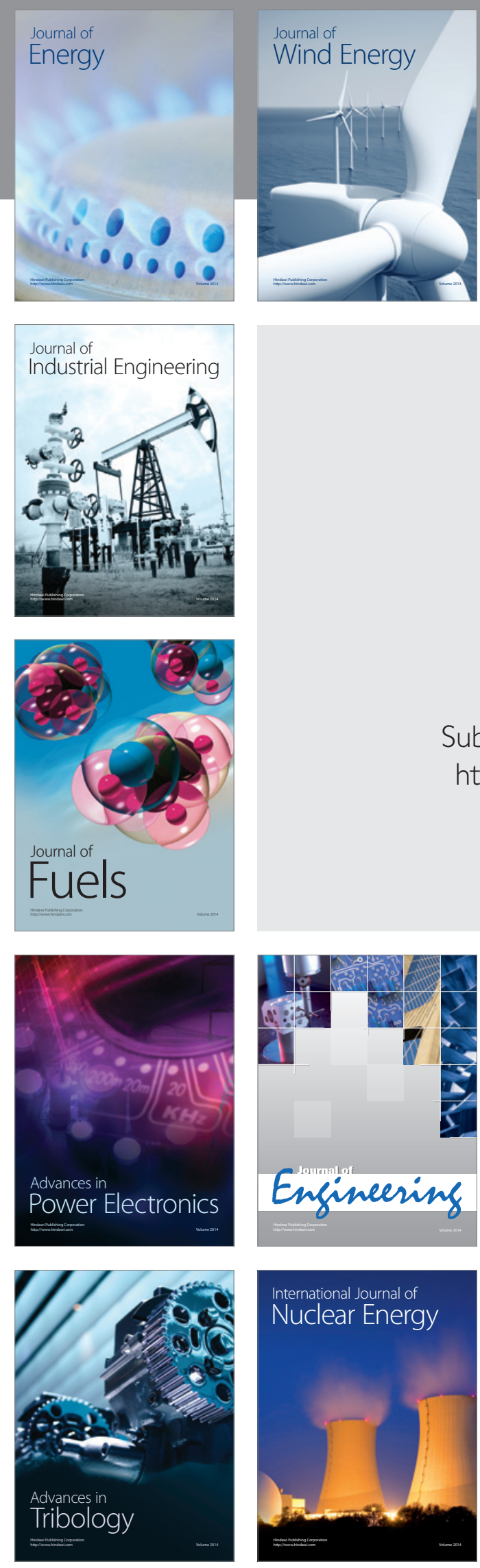

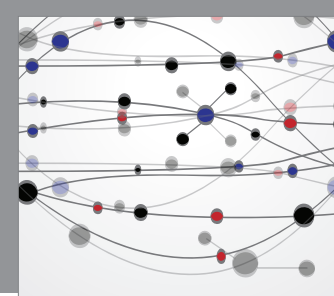

The Scientific World Journal
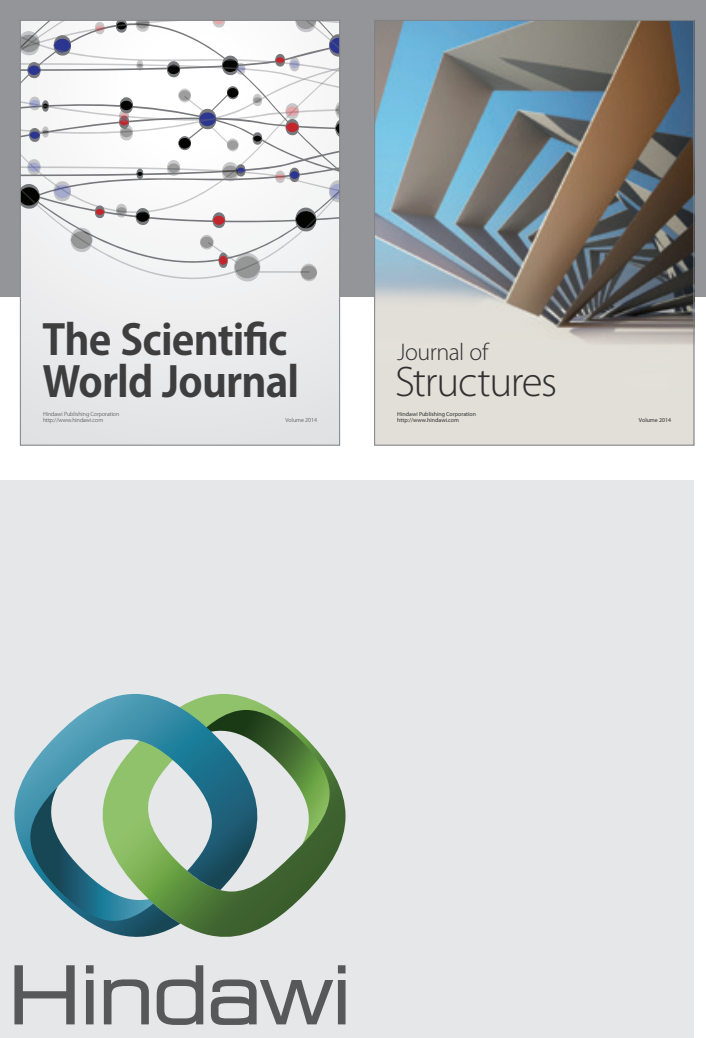

Submit your manuscripts at

https://www.hindawi.com
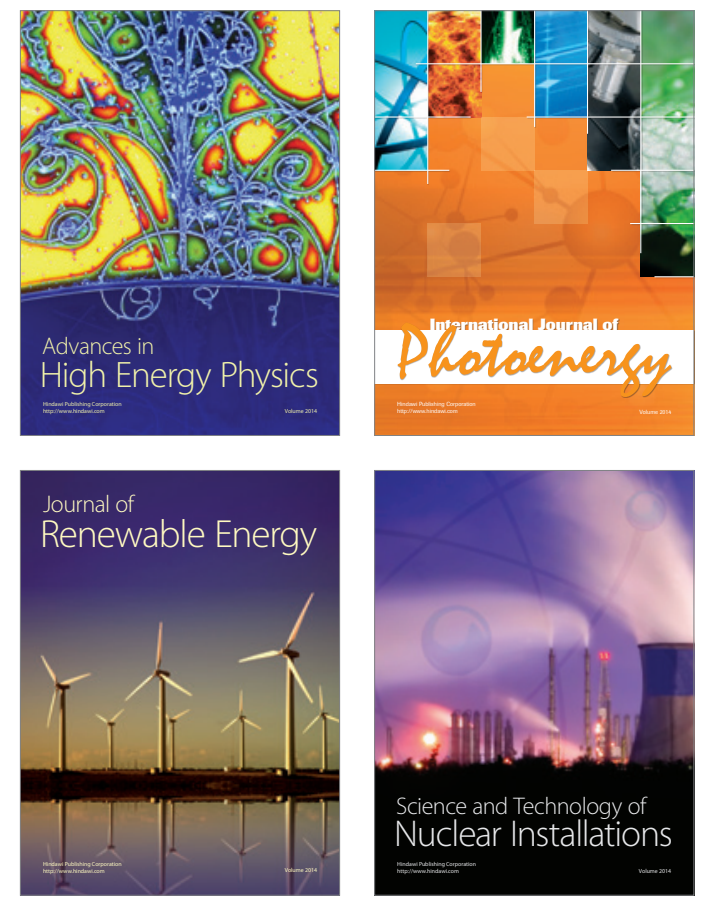
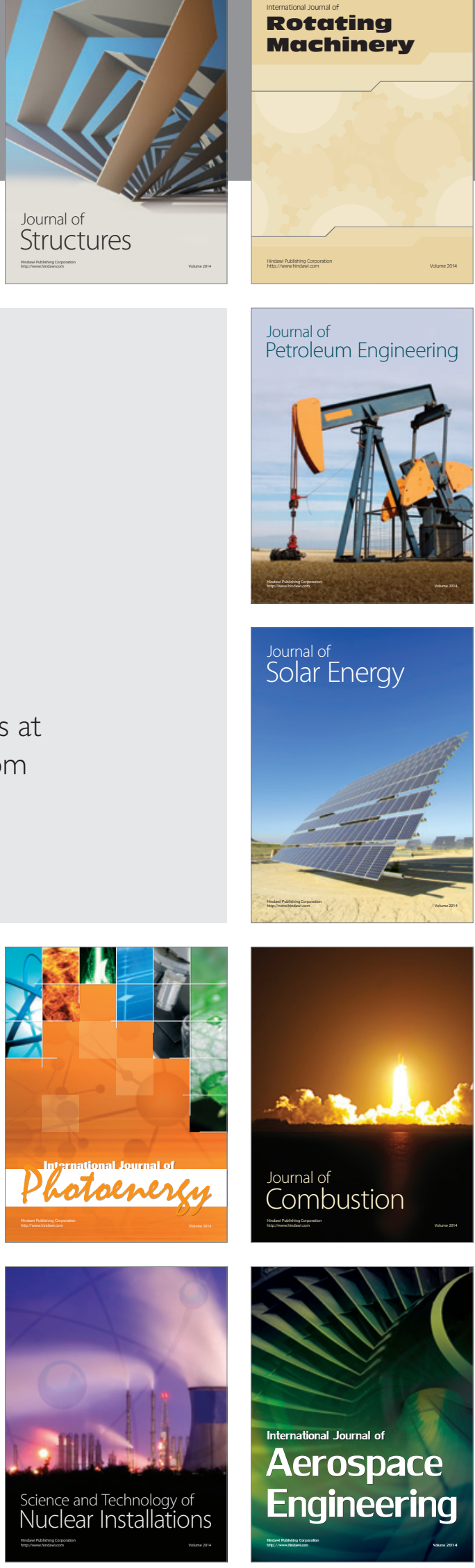